\title{
Presence of virus-like bodies in liver cells of patients with infectious hepatitis
}

\author{
BRENNO BABUDIERI, ${ }^{1}$ ERNICO FIASCHI, REMO NACCARATO, \\ AND LUDOVICO ANTONIO SCURO \\ From the Institute of Health, Laboratories of Microbiology and Physics, Rome, \\ and the Institute of Medical Pathology of the University of Padua, Italy
}

With the technical assistance of J. HAASE, J. PAPA, and F. TANGUCCI

SYNOPSIS Cytoplasmic 'saccules', bordered by monolayer membranes, containing round, virus-like particles, with a diameter of about $200 \AA$, are described in liver cells of 11 patients suffering from viral hepatitis. The differences between this pattern, glycogenic clumps of granules, polysomes, and cytoplasmic autolysis processes are discussed.

During the past few years, numerous investigators have tried to shed light upon the unknown virus of human infectious hepatitis, and many of their findings, considered as positive, have been reported in the medical literature.

From stool and urine specimens and sometimes blood samples, viral agents have been repeatedly isolated, each differing from the other and each successively reported as the 'true' agent of the illness (Rightsel, Keltsch, Tekushan, and McLean, 1956; Kubelka, Slavik, and Soušek, 1958; Bolin, Alsever, Barger, and Jarvis, 1961 ; Rightsel, Keltsch, Taylor, Boggs, and McLean, 1961 ; Chang, 1961 ; O’Malley, Meyer, and Smadel, 1961; Spies, 1962; Lászlo,

'Supported by a grant from the Italian National Research Council. Received for publication 20 June 1966.
Peter, Filep, Abraham, Balint, Domokos, Kasza, Derdi, and Bede, 1963; Buchner and Shreeve, 1964; McLean, 1964; Richter, Rdzok, and Moize, 1964; Liebhaber, Krugman, Giles, and McGregor, 1964). Other authors have observed with the electron microscope virus-like patterns in liver cells of human beings affected by viral hepatitis (Braunsteiner, Fellinger, Pakesch, and Naumayr, 1958; Cassel, 1959, 1961; Bearcroft, 1962; Bearcroft and Peachey, 1962). Not one of these findings has until now been indisputably confirmed, so that the aetiological problem of human viral hepatitis may still be considered open (World Health Organization, 1964).

Using the electron microscope we have attempted to investigate all those relevant aspects of the virus we were looking for in liver cells of patients with infectious hepatitis.

TABLE I

LABORATORY, CLINICAL, AND PATHOLOGICAL FINDINGS IN CASES OF ACUTE INFECTIOUS HEPATITIS

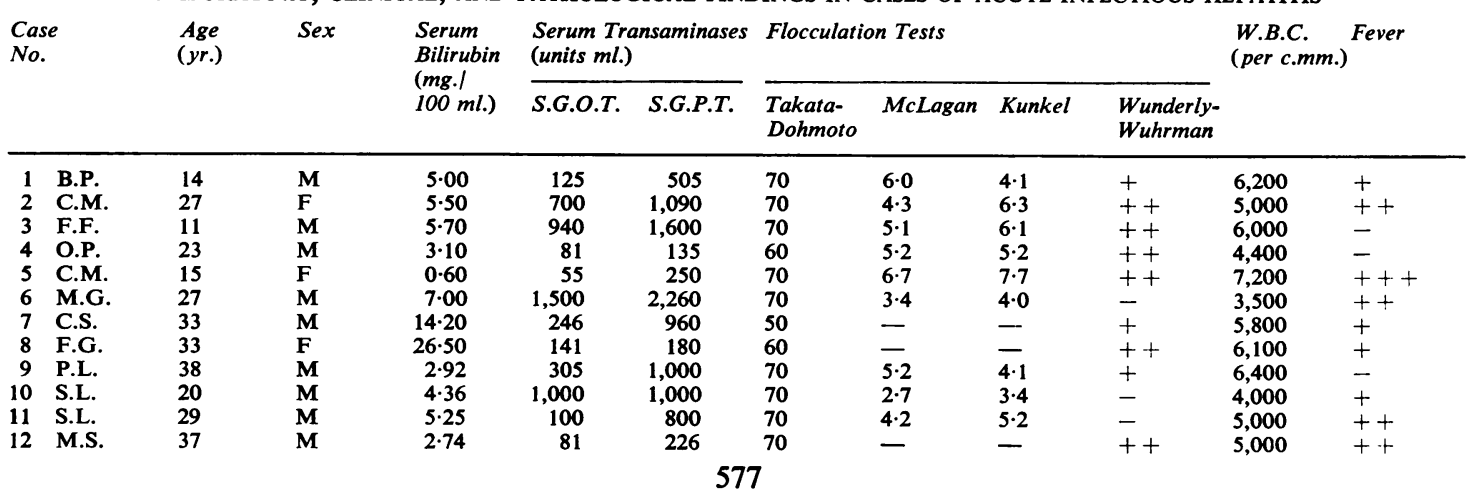


METHODS

Laboratory and clinical data from 12 cases of acute viral hepatitis are summarized in Table I.

Liver tissue was taken from the patient by needle biopsy (Silverman's needle) at the acute stage of the illness. It was immediately fixed in buffered osmium

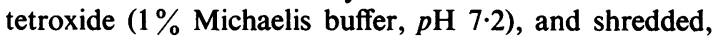
dehydrated, and embedded in the usual fashion in methacrylate or araldite. Thin sections were cut with a Porter Blum microtome and examined under a Siemens Elmiskop I electron microscope. Some of the sections were stained according to Karnowski, others with the uranyl-acetate method. Tissue from healthy human livers treated in the same manner was used as controls.

\section{RESULTS}

Rather than describing the submicroscopic lesions of the liver cells during the course of viral hepatitis, we shall limit ourselves to a description of those morphological findings which possibly have a connexion with the aetiological agent for which we are looking.

In 11 of our patients we have repeatedly found cytoplasmic areas, like a sac, irregularly oval, with $\mathrm{a}^{\mathrm{o}}$ diameter of about 0.4 to $1 \mu$, bordered by a mono $\overrightarrow{\vec{s}}$ layer membrane. In these areas, not highly opaque to the electronic beam, many granular bodies aref irregularly disseminated. They appear round and are about $200 \AA$ in diameter. In addition some of them are irregularly spread throughout the cyto plasm surrounding these sacs (Figs. 1, 2, 3, and 5) The sacs containing the granular bodies are similaị to the viral clumps recently described by Richter and his colleagues in infectious hepatitis of the duck (Richter et al., 1964). Once we observed what coulक be interpreted as the initial stage of development of one of these sacs. It has a cytoplasmic area relatively opaque, bordered by a membrane which is not yet well defined on all sides. At two points in this area, two clear, irregular vacuoles, which contain many granular bodies of the type and size described above, are evident (Fig. 4). We have never found similar patterns in liver cells of healthye people nor in those of patients suffering from diseases other than viral hepatitis.

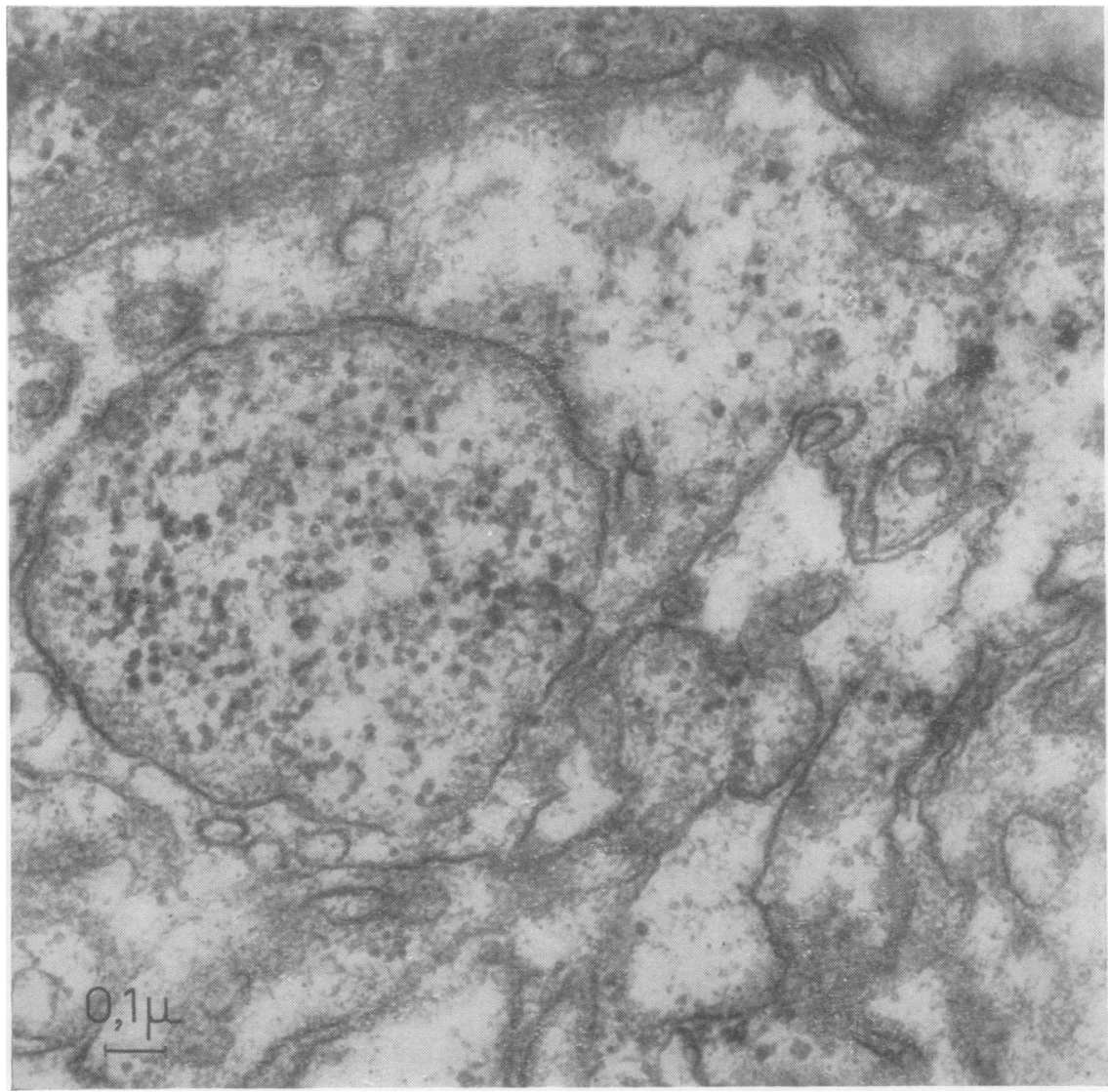

FIG. 1. Sac con- $\frac{\mathrm{O}}{\mathrm{O}}$ taining virus-like bodies (methacrylate $\times 69,000)$. 


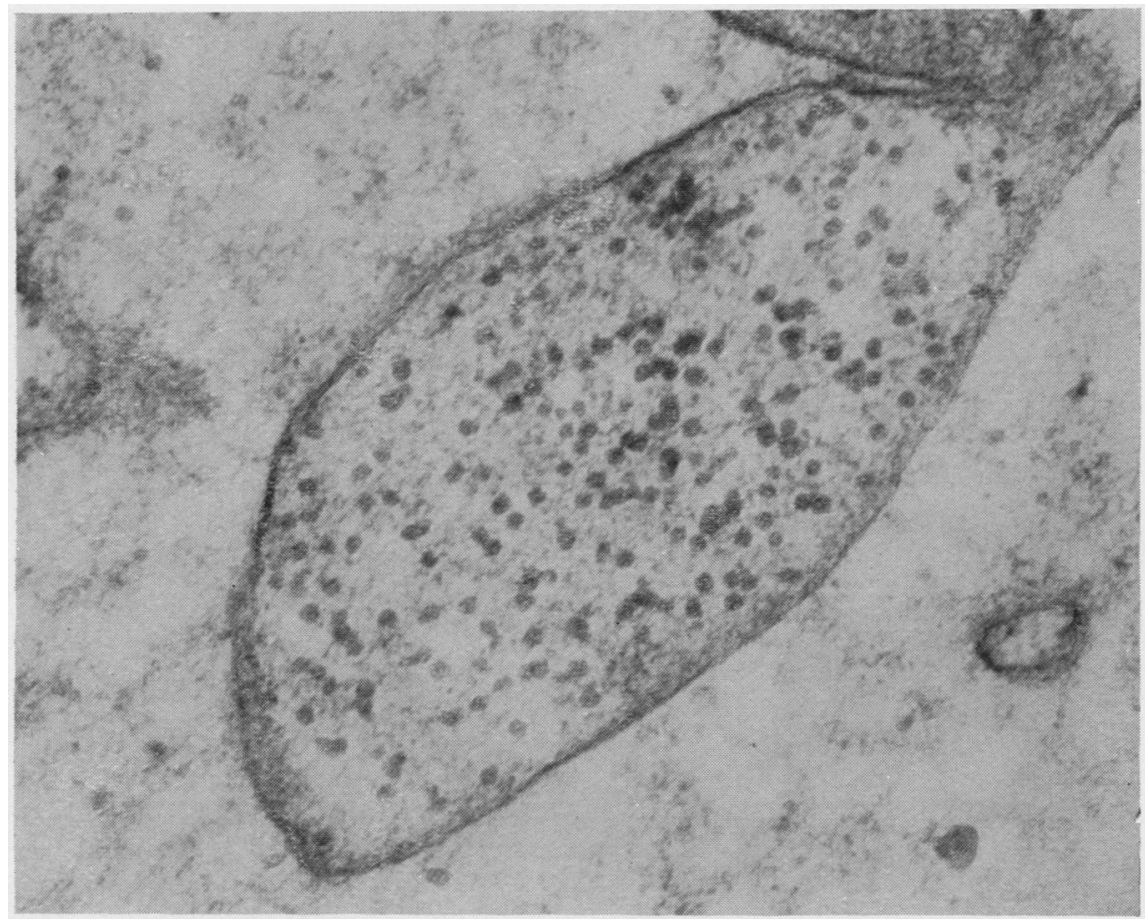

FIG. 2. Sac con-

taining virus-like bodies (methacrylate $\times 75,000)$.

Partially

disintegrated sac containing virus-like bodies (methacrylate $\times 90,000)$.

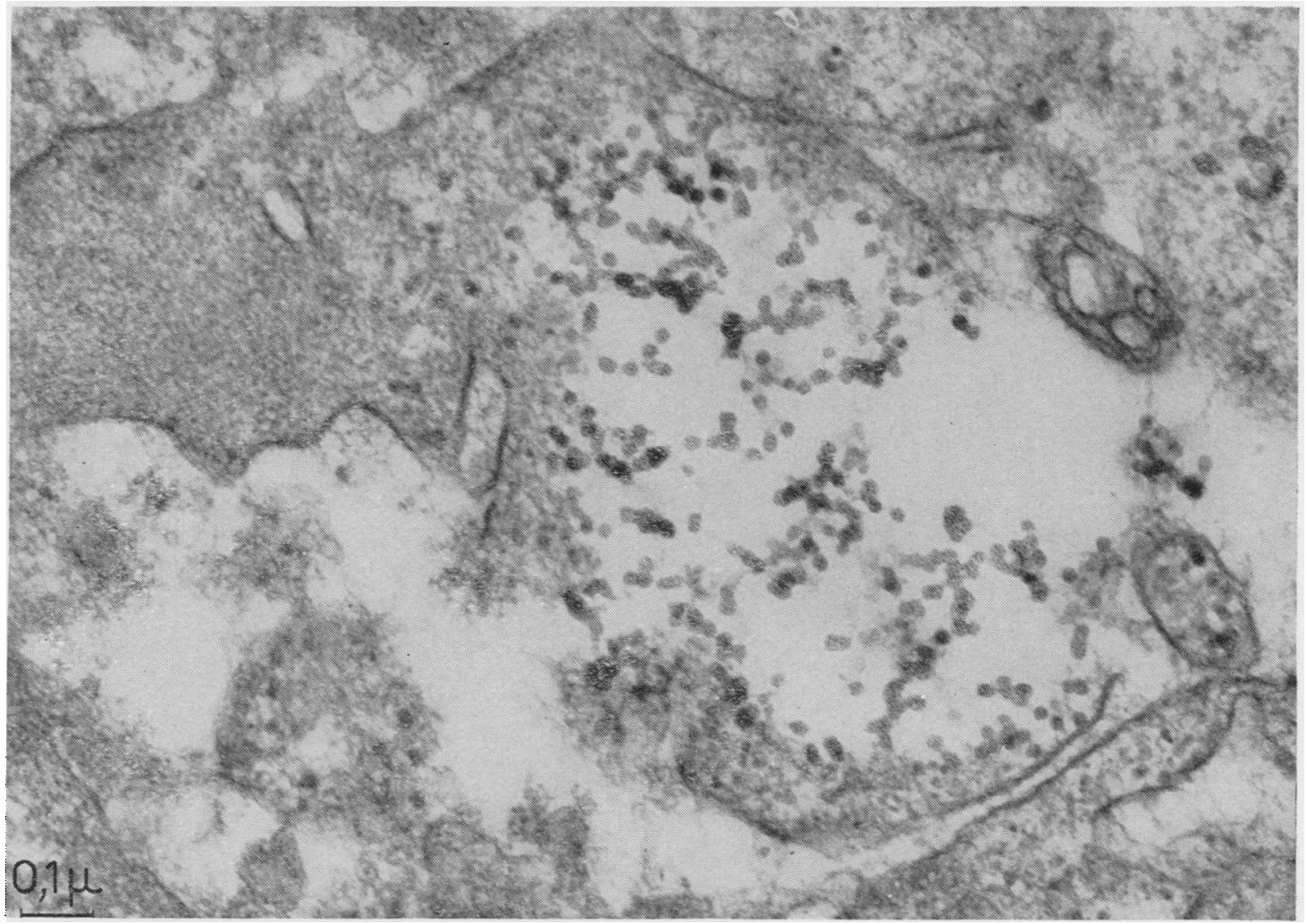




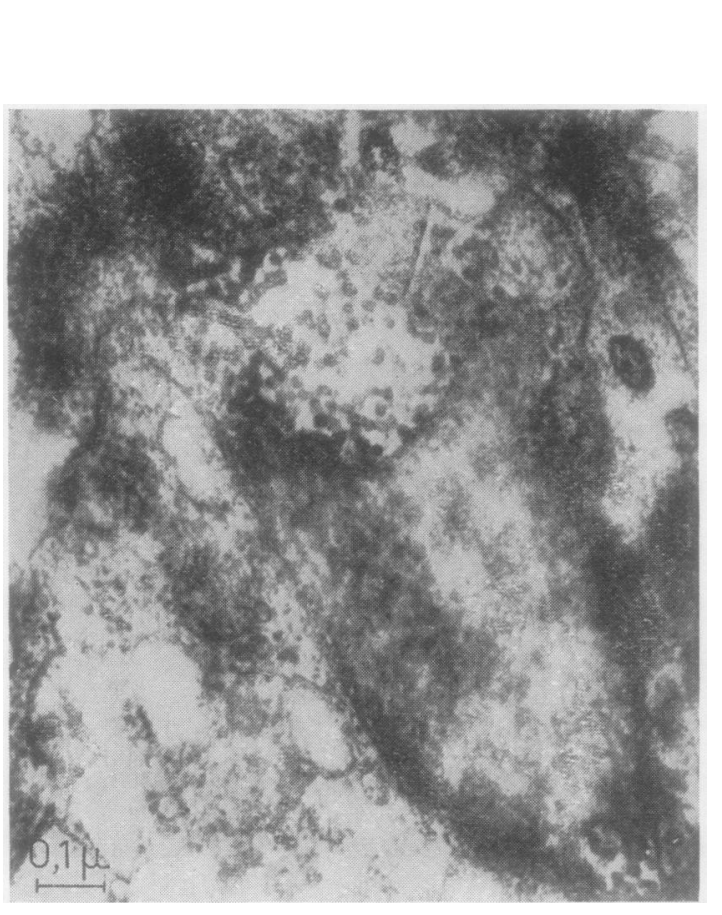

FIG. 4.

FIG. 4. Initial stage (?) of a sac (methacrylate $\times 72,000$.)

FIG. 5. Sac containing virus-like bodies (araldite 120,000).






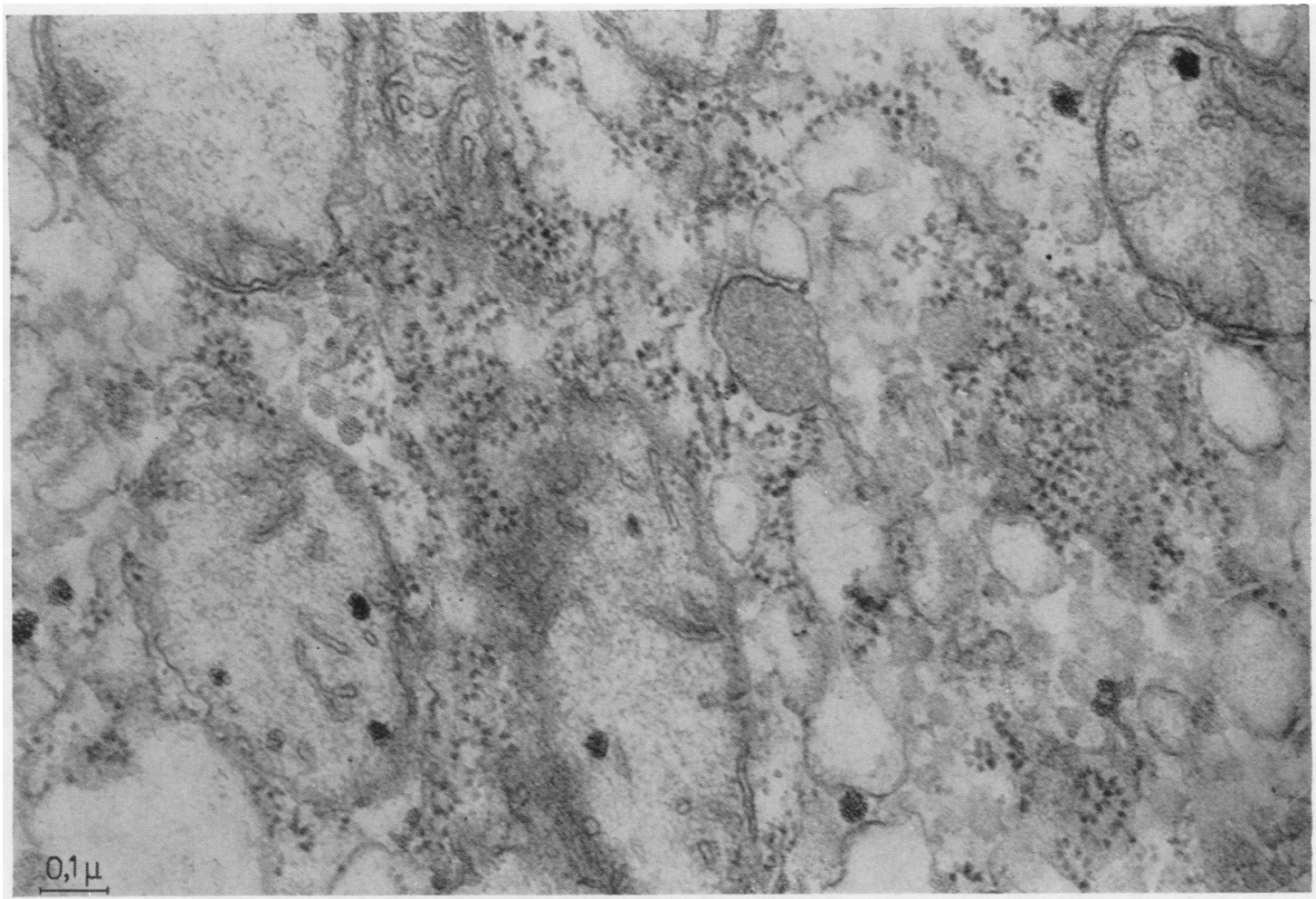

FIG. 6. Ribosomes arranged in parallel lines in a liver cell of a patient with acute viral hepatitis (methacrylate $\times$ $60,000)$.

The diameter of the granule oscillates around $200 \AA$. It is well known that the diameter of a virus in tissue sections, as a consequence of the fixation techniques followed by alcohol-acetone treatment, shrinks by about $30 \%$. If we take this into consideration, we can calculate that our 'fresh' granules are $260 \AA$ in diameter, corresponding exactly to the value found for serum hepatitis virus by McCollum (1952) who used a filtration technique, passing the infected material through graded filtering membranes.

The cells which contain these patterns are sometimes of an epithelial nature which is confirmed by the presence of glycogen in the cytoplasm. But the patterns can also be found in cells of a hystiocytic nature (perhaps in Kupffer's cells), as shown in one case by the presence of some thin fibrils in the cytoplasm of the affected cell. Frequently the saccules are observed very close to the liver sinusoids.

The granules contained in the saccules are easily distinguished from ribosomes and from clumps of glycogen and are not destroyed after treating the sections with diastase (diastase Merck, $1 \%$ diluted

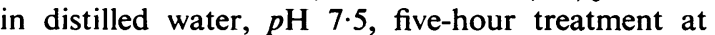

$37^{\circ} \mathrm{C}$.). Apart from the results of this test, these granules differ from the rosette-like clumps of glycogen, as they are uniform in size, perfectly round, and contained within the saccule. There is also a difference between them and the polysomes or clumps of ribosome (Fig. 5) frequently found in liver cells of viral hepatitis patients. The ribosomes are smaller, more triangular than round, and are never contained within the saccule.

The granules we describe may be the final results of a degenerative cytoplasmic process.

Local foci of autolysis are not rare in liver cells of hepatitis patients, and the hypothesis expressed above cannot be firmly rejected on the basis of morphology alone; however, the clumps of granules resulting from cytolytic processes are usually composed of debris of different size and irregular outline, very different from the granules we describe. However, further recent research has led us to believe that the granules described above could correspond, at least partially, to the endothelial type of particulate glycogen described in some endothelial and muscle cells, but not yet observed in the human liver. 


\section{REFERENCES}

Bearcroft, W. G. C. (1962). J. Path. Bact., 83, 383

-

Bolin, V. S., Alsever, J. B., Barger, J. B., and Jarvis, T. B. (1961). Transfusion, 1. 360.

Braunsteiner, H., Fellinger, K., Pakesch, F., and Naumayr, A. (1958). Klin. Wschr., 36, 379.

Buchner, B. K., and Shreeve, M. (1964). Canad. J. publ. Hlth, 55, 299.

Cassel, L. (1959). Klin. Wschr., 37, 1263.

- (1961). Acta hepato.-splenol. (Stuttg.), 8, 333.

Chang, R. S. (1961). Proc. Soc. exp. Biol. (N.Y.), 107, 135.

Kubelka, V., Slavik, K., and Soušek, O. (1958). Zbl. Bakt. I. Abt. Orig., 171, 401 .

Lászlo, J., Peter, M., Filep, D., Abraham, A., Balint, E., Domokos. L., Kasza, L., Derdi, P., and Bede, S. (1963). Vop. Virus., 8 221.

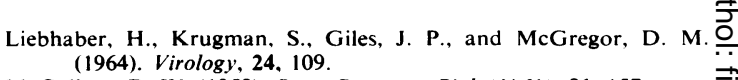

McCollum, R. W. (1952). Proc. Soc. exp. Biol. (N.Y.). 81, 157.

McLean, I. W., Jr. (1964). Postgrad. Med., 35. 481.

O'Malley. J. P., Meyer, H. M.. Jr., and Smadel, J. E. (1961). Proc ত Soc. exp. Biol. (N.Y.), 108, 200.

Richter, W. R., Rdzok. E. J.. and Moize, S. M. (1964). Virology. 24. $\frac{\bar{\sigma}}{\bar{\omega}}$ 114.

Rightsel, W. A., Keltsch, R. A., Taylor, A. R., Boggs, J. D., and $\overparen{D}$ McLean, I. W. J. (1961). J. Amer. med. Ass., 177, 671.

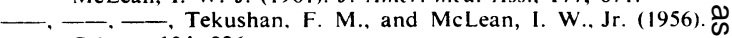
Science, 124, 226.

Spies, K. (1962). Proc. XV Scientific Sessions, Iranovsky Institute of $\overrightarrow{0}$ Virology, Dec. 10-12. 1962.

World Health Organization (1964). Regional Office for Europe. European Symposilim on Viral Hepatitis, Prague, Sept. 29Oct. 3, 1966. 